\title{
Do personality traits predict 'complaining' consumers?
}

\section{Article}

\section{Accepted Version}

Creative Commons: Attribution-No Derivative Works 4.0

Ekinci, Y., Calderon, J. and Siala, H. (2016) Do personality traits predict 'complaining' consumers? Journal of Business Environment, 8 (1). p. 32. ISSN 1740-0597 doi: https://doi.org/10.1504/IJBE.2016.074793 Available at https://centaur.reading.ac.uk/52422/

It is advisable to refer to the publisher's version if you intend to cite from the work. See Guidance on citing.

To link to this article DOI: http://dx.doi.org/10.1504/JJBE.2016.074793

Publisher: Inderscience

All outputs in CentAUR are protected by Intellectual Property Rights law, including copyright law. Copyright and IPR is retained by the creators or other copyright holders. Terms and conditions for use of this material are defined in the End User Agreement.

\section{www.reading.ac.uk/centaur}

\section{CentAUR}

Central Archive at the University of Reading

Reading's research outputs online 


\title{
Do personality traits predict 'complaining' consumers?
}

\section{Yuksel Ekinci*}

The School of Marketing and Reputation, Henley Business School, University of Reading,

Reading, UK

Email: y.ekinci@henley.ac.uk

*Corresponding author

\section{Joana Calderon}

Department of Marketing, Oxford Brookes University, Oxford, UK

Email: Joana.Cald@gmail.com

\section{Haytham Siala}

Roehampton University Business School, University of Roehampton, London, UK

Email: hsiala70@gmail.com

\begin{abstract}
Although the effects of personality traits on complaining behaviour emerged in the early 1980s, there is limited research in the service industry. The purpose of this study is to examine whether consumer personality traits influence intentions to complain and whether product price and product types moderate the relationship between personality traits and intentions to complain in the retail industry. The research model is tested by logistic regression analysis on two groups of consumers who report passive and active complaining intentions. The study reveals that conscientious consumers who are open to new experiences tend to have higher intentions to complain. Being extroverted does not have any influence on complaining behaviour. Whilst price levels (low/high) and product types (grocery, clothing and electronics) improve the predictive ability of the complaining behaviour, the interaction effects relating to the three personality traits are statistically insignificant. Theoretical and managerial implications of the study findings are discussed.
\end{abstract}

Keywords: complaining behaviour; personality traits; retailing.

Reference to this paper should be made as follows: Ekinci, Y., Calderon, J. and Siala, H. (xxxx) 'Do personality traits predict 'complaining' consumers?', Int. J. Business Environment, Vol. X, No. Y, pp.000-000. 
Biographical notes: Yuksel Ekinci is a Professor of Marketing of Henley Business School at the University of Reading. His research interests include scale development, service quality, consumer satisfaction, consumer loyalty and brand equity. His articles are published in the European Journal of Marketing, the Journal of Business Research, the Service Industries Journal, the International Journal of Human Resource Management, the Journal of Travel Research and Annals of Tourism Research. He is a member of editorial board for several marketing journals such as the Journal of Retailing and Consumer Services and Journal of Travel Research.

Joana Calderon received her MSc in Business Management from Oxford Brookes University and is an Account Manager who focuses on digital marketing and communications at a creative agency based in Marlow.

Haytham Siala is a Senior Lecturer in Marketing and Digital Media at the Business School, Roehampton University. His research interests include cross-cultural consumer behaviour, religious brand management and services marketing, TAM, and the role of technology as a pedagogical facilitator of the learning process. His articles are published in the Journal of Services Marketing, Journal of Business Ethics, Information System Frontiers, and Interacting with Computers. He is also a peer reviewer for the Service Industries Journal and Information System Frontiers.

\section{Introduction}

A defective product will often result in customer dissatisfaction and prompt a variety of undesirable behavioural responses such as complaining, negative word-of-mouth (WoM), switching supplier and to stop purchasing the product. If a customer complaint arises, compensation or service recovery tactics will likely win the customer over.

However, this assumption does not take into consideration the fact that $90 \%$ of dissatisfied customers will not express their negative feelings to the service provider (Tax and Brown, 1998). Dissatisfied customers who do not complain are of special concern to management. This is because they miss the opportunity to remedy the problem and deprive themselves of valuable feedback that could be used to improve their products. A failure to detect customer complaints can also damage the brand reputation as customers engage with negative WoM (Stephens and Gwinner, 1998).

Generally speaking, dissatisfied consumers tell more people about their poor experiences than those who are satisfied or even delighted with their product experience (Bolfing, 1989). In today's digital marketing environment, negative WoM can be more quickly disseminated to reach a potentially large audience and influence consumer decision-making due to the increasing popularity of social media (Liang et al., 2013).

Negative WoM can be accessed immediately or after a period of time; its digital footprint can remain online permanently (Sun et al., 2006). It is therefore important for marketers to understand the antecedents of consumer complaining behaviour (CCB); to gain an idea of what prompts people to complain and to minimise those adverse effects on business performance.

This study unveils two contributions to this research. Firstly, although the effects of personality traits on predicting complaining behaviour first emerged in the early 1980s, there is limited research on this topic, particularly in the retail industry which is 
dominated by consumer-buyer interaction and involves a wide range of services and goods (Bearden and Mason, 1984; Krapfel, 1985; Richins, 1983). Previous research is predominantly focused on three broad factors to explain the propensity of complaining behaviour - market conditions (Hirschman, 1970), organisation and product characteristics (Granbois et al., 1997) and socio-demographic characteristics (e.g., age, gender, income and attitudes towards complaining) (Bolfing, 1989; Lee and Soberon-Ferrer, 1999). This study also takes into consideration two prominent product related characteristics to understand CCB: price and product type.

Secondly, when specifically investigating the ability of personality traits to predict complaining behaviour, previous studies have produced mixed or inconclusive results, causing interesting debates. Therefore, additional research would be fruitful in addressing these debates. For example, Kenrick and Funder (1988) and Mishel (1984) argue that personality is not a good predictor of behaviour. Bodey and Grace (2007) agree with the arguments of Kenrick and Funder (1988) and Mishel (1984) as their research did not find support for the effect of three personality characteristics - self-efficacy, Machiavellianism, perceived control - on propensity to complain with the exception of risk-taking. To enhance the predictive ability of personality traits, Harris and Mowen (2001) introduced a hierarchical model of personality and consumer intentions to complain. This showed that a set of central and surface level traits such as value consciousness and materialism mediate the influence of personality traits on the intention to complain.

Whilst there is limited research on this topic, even less research is available on the investigation into whether product related characteristics (e.g., price and product type) moderate the relationship between personality traits and complaining behaviour. Therefore, this study aims to add clarity to the existing debate of whether personality has an effect on the intention to complain and if product price and product type moderate the relationship between personality traits and intentions to complain.

\section{Conceptual framework}

What is CCB? The simplest way to answer this question is to say that CCB is the "set of multiple behavioural and non-behavioural responses, some or all of which are triggered by perceived dissatisfaction with a purchase episode” [Singh, (1988), p.94]. Hirschman's (1970) model of CCB, one of the earliest theories, identifies three major types of complaining behaviour outcomes: exit, voice, and loyalty. For this model, 'loyalty' refers to the consumer taking no action what-so-ever despite dissatisfaction with a product; often these consumers are so loyal that they strongly believe the problem will get better with time and on its own. 'Exit' is rather less passive and involves the consumer actively rejecting the brand or company; often buying other brands instead or maybe just buying less of the said product. When consumers 'voice' their complaint, they do so directly to the company through either employees or management. Day and Landon (1977) had similar attributes to Hirschman's model but separated CCB into several levels of response. The first level of this particular model is the dissatisfaction with a product which then splits into categories of action with no action at the second level.

If a consumer decides to take action a third level appears whereby the consumer chooses between a public or private action. At the fourth level, public actions include: 
seeking redress (amends or reimbursement) directly from the business, complaining to the business or government agency or taking legal action. If the consumer decides on a more private route, the fourth level includes: warning others (friends/family) about the product and no longer buying the product. This is quite similar to Hirschman's (1970) 'Exit' typology.

As a result of these two typologies, Singh (1988) proposed that 'no action' be treated as a type of voice response rather than a passive behaviour. Under this typology, the 'voice' response is similar to the terminology used in the other two models. Nonetheless, it does refer to behaviour directed toward the business whether in person, through a phone call, or even a letter. No action, as already mentioned, is a voice response because "taking no action appears to reflect feelings towards the seller" [Singh, (1988), p.104]. Private responses include exit and warning to family and friends (also classified as negative WoM). Third-party action is similar to 'public action' mentioned in the previous model, but seeking redress is now a voice response. Under this category, the consumer is in essence, complaining through a third-party; someone other than the actual business they made their purchase through.

Personality is defined as abstractions (or traits such as conscientiousness) of behaviour that determines the pattern of interaction with the environment (McKenna, 2000). Personality can be observed, because behaviour is directly affected by the personality of the individual. The characteristics that make up personality are unique; they may or may not be present in an individual, vary in intensity, therefore ultimately make the individual unique.

This resurgence was facilitated in part by the emergence of a consensus of understanding in that traits are well structured within five broad, empirically driven domains. These are known as 'Five Factor Model' or 'Big Five' and consist of extroversion, agreeableness, conscientiousness, emotional stability, and openness to experience. The openness to experience personality trait is interpreted to reflect not only a facet of creativity and innovation, but also intellect. These five domains encompass narrower, more context-specific facets in a hierarchy of individual differences and have been validated through many empirical studies. Therefore, they are considered to be the fundamental dimensions of human personality. Existing studies suggest that complainers tend to be more assertive and self-confident, having higher levels of aggression than non-complainers (Richins, 1987; Phau and Sari, 2004). Assertive and self-confident people are more likely to complain, whereas submissive and unconfident individuals are more likely to keep quiet (Bolfing, 1989; Fornell and Westbrook, 1979). Chang and Wang's (2008) study in a virtual market environment suggests that when e-service failures occur, internally oriented consumers engage in aggressive complaint behaviours and expect high service recovery efforts. This is in comparison to externally oriented consumers who tend to tolerate e-service failures and refrain from complaining.

Based on previous work, this study proposes that three types of personality traits; extroversion (H1), conscientiousness (H2) and openness to experience (H3) will have a positive influence on the intentions of consumers to complain as shown in Figure 1. 
Figure 1 Conceptual framework

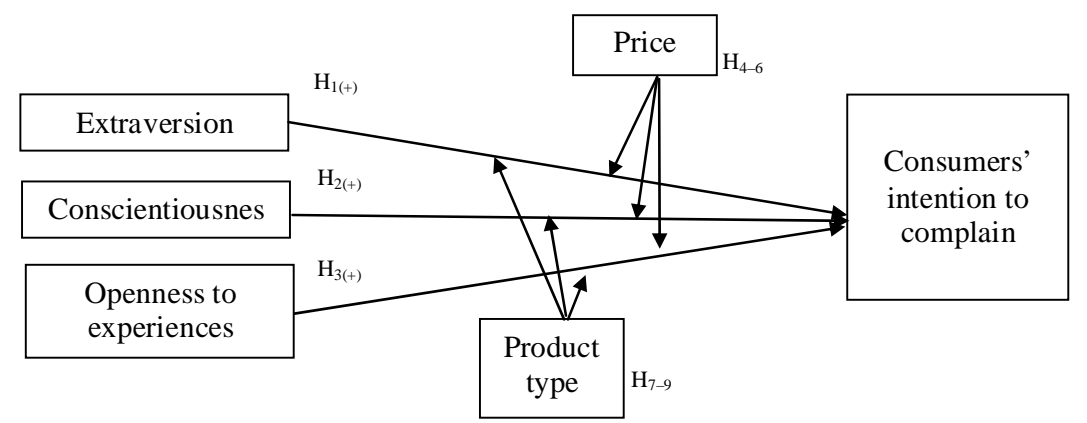

As Figure 1 shows there are no prior hypotheses relating emotional stability or agreeableness to CCB. Moreover, this model also proposes that the effects of personality traits on CCB are moderated by product price (H4, H5, and H6) and product type 1 (H7, H8, and H9). Research hypotheses are discussed in the following section.

\subsection{Effects of personality traits on complaining intentions}

Although the history of personality research goes back to early 19th century with decades of diverging theories and mixed results, its revitalisation and popularity has gained dramatic insurgence in the past 20 years in marketing research. This reappearance was enabled partly by the emergence of an agreement in understanding of personality traits with five broad domains (e.g., The Five factor model or Big Five).

Hence, personality traits have been adopted to study a variety of behavioural and psychological responses such as consumer satisfaction, consumer values, emotions, compulsive buying and purchase loyalty in marketing research (Matzler et al., 2006). In this study, we focus on three personality traits that are expected to be positively related to CCB: Extraversion, conscientiousness, and openness to experience.

Extroverted people are frequently described as sociable, gregarious, assertive, talkative, and active (Barrick and Mount, 1991). In increasing levels, 'assertiveness, self-confidence and personal control over ones' own life experiences can lead to a higher probability to complain' (Bolfing, 1989). Those individuals who score high on extroversion tend to complain more than those with lower score (Thøgersen et al., 2009). According to Keng et al. (1995) and Phau and Sari (2004), consumer assertiveness and confidence are found to be linked to CCB, whilst non-assertive consumers are oppositely linked (Singh, 1990). Richins (1987) discovers that consumers with higher levels of aggression and assertiveness tend to be typed as complainers. Bodey and Grace (2007) suggest that attitude towards complaining, and self-monitoring levels are significantly different between confident and unconfident people. In a study by Phau and Sari (2004) in Indonesia, they found that those consumers who were complainers were typically of higher income and education; they exhibited greater self-confidence, were more willing to take risks, and had a positive attitude toward complaining. Complainers invariably also had a high sense of justice and were less conservative (Phau and Baird, 2008). 
Conscientious individuals are described as organised, dependable, responsible, punctual, self-disciplined, hardworking and achievement-oriented (Barrick and Mount, 1991). Because of these positive characteristics, conscientious people tend to display effective interaction with other people and are better at managing conflicts (Roberts et al., 2009). If a product is not satisfactory, conscientious people are likely to complain as they exhibit traits associated with a strong sense of purpose, obligation, persistence and intolerance to poor performance (Harris and Mowen, 2001).

According to Barrick and Mount (1991), openness to experience means a person is imaginative, creative, open-minded and analytical. Individuals who achieve high scores on the openness scales are less conservative and more likely to have positive attitudes towards learning experiences in general (Barrick and Mount, 1991). They are curious about both inner and outer worlds and open to accept new ideas and unconventional values and therefore they experience both negative and positive emotions more profoundly than do closed individuals. Open individuals are motivated to seek out the unfamiliar and to look for complexity (Costa and McCrae, 1992). As they are more likely to experience both positive and negative emotions and they are more willing to complain when products fail. Thus, we propose:

H1 Extraversion is positively associated with the intention to complain by consumers.

H2 Conscientiousness is positively associated with the intention to complain by consumers.

H3 Openness to experiences is positively associated with the intention to complain by consumers.

\subsection{The moderating effect of price on the relationship between personality traits and complaining intentions}

Complaints are more likely occur when there is a big loss for the customer (Thøgersen et al., 2009). Lilleker et al. (1969) find that price of the product had vast amount to do with whether a consumer decided to complain. Broadbridge and Marshall (1995) report that the price of a product correlates to whether or not a consumer decides to complain. The more expensive the product is the more likely the consumer is to complain if it is unsatisfactory. Thus, we propose:

H4-H6 Product price moderates the effects of extraversion, conscientiousness and openness to experiences on the intention to complain by consumers.

\subsection{The moderating effect of product category on the relationship between personality traits and complaining intentions}

A variety of product characteristics can influence the reactions to dissatisfaction. Two major reasons for complaints are defective and unsatisfactory products. The more satisfactory and durable the product is in the eyes of the consumer, the less likely they will be subject to complaining (; Best and Andreasen, 1977). Generally speaking, consumers avoid complaining about low-cost, low-involvement products such as non-durables (Day and Landon, 1977). They are more likely to complain if a product is considered important or if the product fault is serious and complex (Bolfing, 1989; Richins, 1983). Furthermore, dissatisfied customers are more likely to complain when 
service failure occurs during a high-involvement purchase, such as dining out on a special occasion or having an expensive meal (Kim and Chen, 2010).

Thus, we propose:

H7-H9 Product type moderates the effects of extraversion, conscientiousness and openness to experiences on the intention to complain by consumers.

\section{Method}

To investigate the moderating effect of product price (low/high) and product type on the relationship between personality traits and CCB, a $2 \times 3$ quasi-experimental research design was employed. The experiments included 6 product failure scenarios involving high and low prices and three different retail product areas: grocery, fashion retail and electronics (see Appendix). These retail products were chosen because UK retail sales amount to around $£ 300$ bn pa. The UK is also the third largest retail industry behind the USA and Japan (Department for Business, Innovation and Skills, 2012). Overall, UK retail has a $6 \%$ share of the top 250 global retailers as well as a share of $6.5 \%$ of sales made by those same top 250 retailers (Deloitte, 2012). The industry itself contributes $11.3 \%$ of total gross value added to the UK economy, provides $10 \%$ of total employment and accounts for more than a third of consumer spending (Department of Business Innovation and Skills, 2012).

Measurement of consumer personality was based on the Big-Five framework, which is the most widely used and extensively researched personality model.

Extraversion, conscientiousness and openness to experience were measured using a seven-point Likert type scale ranging from (1) extremely disagree to (7) extremely agree (Ekinci and Dawes, 2009). Based on CCB literature, the intention to complain by consumers was measured by six nominal (yes/no) scales (e.g., negative WoM and seeking compensation). After reading the six retail products failure scenarios, respondents were asked to register their intention to complain based on these scales. Thereafter, the measures were used to form two groups according to Hirshman's (1970) typology: passive and active complaining.

A total of 93 people participated in the study. As each individual responded to the six experimental scenarios their responses were pooled. The pooled data of 558 responses $(93 \times 6)$ were used to test the research model. The sample consisted of $62 \%$ female and $38 \%$ male respondents. Approximately, $62 \%$ of participants were within the group aged 18-25 years of age. This was followed by the 26-34 year olds (21\%) and the 35-44 year old group (13\%). $44 \%$ of participants indicated that they earned less than $£ 10,000$ annually before taxes.

\section{Findings}

Before testing the model, validity of the personality measures were established through exploratory factor analysis with the varimax rotation. As expected, the three personality traits explained $75 \%$ of the total variance. Factor loadings were substantially high and had no cross loadings. These findings supported the construct validity of personality measures. The internal consistency reliability of the personality measures were also 
acceptable because they exceeded the recommended Cronbach alpha value of 0.70 (Churchill, 1979) $-($ Extraversion $=0.77$, conscientiousness $=0.73$, and openness to experience $=0.71$ ).

The primary model testing method was logistic regression through the use of the Baron-Kenny method (Baron and Kenny, 1986). The first logistic regression model including the three personality measures had a statistically significant relationship with intentions to complain $(-2$ Log likelihood $=417.848, p<0.05$, Cox and Snell R-square $=0.04$, Nagelkarke R-square $=0.08$, Overall percentage of correct classification $=0.86$ ). Of the three personality traits, conscientiousness and openness to experience were statistically significant $(\mathrm{p}<0.01)$. Therefore, H2 and H3 were supported. H1 posited that extraversion had a positive relationship with CCB, so was therefore rejected.

The second regression model including price level, product type and their interaction effects with personality traits displayed better fit than the first model $(-2$ Log likelihood $=417.848, \mathrm{p}<0.05$, Cox and Snell R-square $=0.17$, Nagelkarke R-square $=0.31$, Overall percentage of correct classification $=0.87$ ). As expected, the price level and two product types - clothing and electronics, had a statistically significant influence on the intention to complain $(\mathrm{p}<0.01)$. However, none of the interaction variable in the model had a statistically significant effect on complaining intentions. Therefore, H4 to H9 were partially supported.

\section{Conclusions}

Overall, results of the study contribute to the ongoing debate as to whether consumer complaining intentions are motivated by personality traits. As two of the three personality traits, conscientiousness and openness to experience had a statistically significant relationship with the intention to complain by consumers, this finding provides support to the major premise that personality traits can be potential predictors for CCB. The findings partly support Harris and Mowen (2001) who found that complaint propensity was positively influenced by conscientiousness and extraversion. However, contrary to their findings this study did not find that extroversion had a statistically significant influence on the intention to complain by consumers. Acting upon their review, this study also employed quasi-experimental research to investigate the effect of product price and product type on complaining intentions. The study found that more expensive products (e.g., French Wine) are likely to motivate a higher intention to complain compared to cheaper products. Similarly, clothing and electronic products are likely to influence a higher intention to complain as compared to grocery products. However, the study findings suggest that price and product type do not necessarily interact with personality variables to generate higher intentions to complain. These two factors act independently from personality traits. In other words, consumers are likely to complain actively when an expensive product, electronic product or a clothing product, are unsatisfactory.

The knowledge gained from this study can be used to understand the complaining intentions of consumers. A customer who has made the effort to voice dissatisfaction or seek redress for an unsatisfactory purchase may be motivated by conscientiousness, open to experiences, product price or high involvement products. The combinations of these psychological and product related characteristics signal the importance of taking caution when dealing with customers who complain or are likely to complain. Therefore, this 
knowledge can also be used to develop effective complaint management programs and the training of employees in the management of consumer complaints.

Two potential limitations of this study are the sample size and product type.

Although the sample covered a wide range of consumers and the product type included three different products categories from the retail industry, the results cannot be generalised to the whole consumer population and other industries. A larger sample and different product categories will offer a more generalised result.

\section{References}

Baron, R.M. and Kenny, D.A. (1986) 'The moderator-mediator variable distinction in social psychological research: conceptual, strategic, and statistical considerations', Journal of Personality and Social Psychology, Vol. 51, No. 6, pp.1173-1182.

Barrick, M.R. and Mount, M.K. (1991) 'The big-five personality dimensions and job performance: a meta analysis’, Personnel Psychology, Vol. 44, No. 1, pp.1-26.

Bearden, W.O. and Mason, J.B. (1984) 'An investigation of influences on consumer complaint reports', Advances in Consumer Research, Vol. 11, No. 1, pp.490-495.

Best, A. and Andreasen, A.R. (1977) 'Consumer response to unsatisfactory purchases: a survey of perceiving defects, voicing complaints, and obtaining redress', Law and Society Review, Vol. 11, No. 4, pp.701-742.

Bodey, K. and Grace, D. (2007) 'Contrasting 'complainers' with 'non-complainers' on attitude toward complaining, propensity to complain, and key personality characteristics: a nomological look’, Psychology \& Marketing, Vol. 24, No. 7, pp.579-594.

Bolfing, C.P. (1989) 'How do customers express dissatisfaction and what can service marketers do about it?', Journal of Services Marketing, Vol. 3, No. 2, pp.5-23.

Broadbridge, A. and Marshall, J. (1995) 'Consumer complaint behaviour: the case of electrical goods', International Journal of Retail \& Distribution Management, Vol. 23, No. 9, pp.8-18.

Chang, H.H. and Wang, I.C. (2008) 'An investigation of user communication behavior in computer mediated environments’, Computers in Human Behavior, Vol. 24, No. 5, pp.2336-2356.

Churchill Jr., G.A. (1979) 'A paradigm for developing better measures of marketing constructs', Journal of Marketing Research, Vol. 16, No. 1, pp.64-73.

Costa Jr., P.T. and McCrae, R.R. (1992) 'Four ways five factors are basic', Personality and Individual Differences, Vol. 13, No. 6, pp.653-665.

Day, R.L. and Landon Jr., E.L. (1977) 'Toward a theory of consumer complaining behavior', in Woodside, A.G., Bennett, P.D. and Sheth, J.N. (Eds.): Foundations of Consumer and Industrial Buying Behavior, pp.425-437, American Elsevier, New York.

Deloitte (2012) [online] http://www2.deloitte.com/uk/en.html (accessed 25 November 2012).

Department for Business, Innovation and Skills (2012) [online] http://www.gov.uk/government/ organisations/department-for-business-innovation-skills (accessed 31 August 2012).

Ekinci, Y. and Dawes, P.L. (2009) 'Consumer perceptions of frontline service employee personality traits, interaction quality, and consumer satisfaction', The Service Industries Journal, Vol. 29, No. 4, pp.503-521.

Fornell, C. and Westbrook, R.A. (1979), 'An exploratory study of assertiveness, aggressiveness, and consumer complaining behavior', Advances in Consumer Research, Vol. 6, No. 1, pp.105-110.

Granbois, D., Summers, J. and Frazier, G. (1997) 'Correlates of consumer expectations and complaining behaviour', in Day, R.L. (Ed.): Consumer Satisfaction, Dissatisfaction and Complaining Behavior, pp.18-25, Indiana University, Bloomington. 
Harris, E.G. and Mowen, J.C. (2001) 'The influence of cardinal-, central-, and surface-level personality traits on consumers' bargaining and complaint intentions', Psychology \& Marketing, Vol. 18, No. 11, pp.1155-1185.

Hirschman, A.O. (1970) Exit, Voice, and Loyalty: Responses to Decline in Firms, Organizations, and States, Harvard University Press, Cambridge, MA.

Keng, K.A, Richmond, D. and Han, S. (1995) 'Determinants of consumer complaint behaviour: a study of Singapore consumers', Journal of International Consumer Marketing, Vol. 8, No. 2, pp.59-76.

Kenrick, D.T. and Funder, D.C. (1988) 'Profiting from controversy: lessons from the person-situation debate', American Psychologist, Vol. 43, No. 1, p.23.

Kim, J-H. and Chen, J.S. (2010) 'The effects of situational and personal characteristics on consumer complaint behaviour in restaurant services', Journal of Travel \& Tourism Marketing, Vol. 27, No. 1, pp.96-112.

Krapfel Jr., R.E. (1985) 'A consumer complaint strategy model: antecedents and outcomes', Advances in Consumer Research, Vol. 12, No. 1, pp.346-350.

Lee, J. and Soberon-Ferrer, H. (1999) 'An empirical analysis of elderly consumers' complaining behavior’, Family and Consumer Sciences Research Journal, Vol. 27, No. 3, pp.341-371.

Liang, S.W., Ekinci, Y., Occhiocupo, N. and Whyatt, G. (2013) 'Antecedents of travellers' electronic word-of-mouth communication', Journal of Marketing Management, Vol. 29, Nos. 5-6, pp.584-606.

Lilleker, C.Y., Mapes, R.E.A. and Riley, C.S. (1969) 'Determinants of consumer complaints', European Journal of Marketing, Vol. 3, No. 4, pp.218-222.

Matzler, K., Bidman, S. and Gabner-Krautzer, S. (2006) 'Individual determinants of brand affect: the role of the personality traits of extraversion and openness to experience', Journal of Product and Brand Management, Vol. 15, No. 7, pp.427-434.

McKenna, E.F. (2000) Business Psychology and Organisational Behaviour: A Student's Handbook, 3rd ed., Psychology Press, New York.

Mishel, M.H. (1984) 'Perceived uncertainty and stress in illness', Research in Nursing \& Health, Vol. 7, No. 3, pp.163-171.

Phau, I. and Baird, M. (2008) 'Complainers versus non-complainers retaliatory responses towards service dissatisfactions’, Marketing Intelligence \& Planning, Vol. 26, No. 6, pp.587-604.

Phau, I. and Sari, R.P. (2004) 'Engaging in complaint behaviour: an Indonesian perspective', Marketing Intelligence \& Planning, Vol. 22, No. 4, pp.407-426.

Richins, M.L. (1983) 'Negative word-of-mouth by dissatisfied consumers: a pilot study', Journal of Marketing, Vol. 47, No. 1, pp.68-78.

Richins, M.L. (1987) 'A multivariate analysis of responses to dissatisfaction', Journal of the Academy of Marketing Science, Vol. 15, No. 3, pp.24-31.

Roberts, B.W., Jackson, J.J., Fayard, J.V., Edmonds, G. and Meints, J. (2009) 'Conscientiousness', in Leary, M.R. and Hoyle, R.H. (Eds.): Handbook of Individual Differences in Social Behavior, pp.257-273, The Guildford Press, London.

Singh, J. (1988) 'Consumer complaint intentions and behavior: definitional and taxonomical issues’, Journal of Marketing, Vol. 52, No. 1, pp.93-107.

Singh, J. (1990) 'A typology of consumer dissatisfaction response styles', Journal of Retailing, Vol. 66, No. 1, pp.57-99.

Stephens, N. and Gwinner, K.P. (1998) 'Why don’t some people complain? A cognitive-emotive process model of consumer complaint behavior', Journal of the Academy of Marketing Science, Vol. 26, No. 3, pp.172-189.

Sun, T., Youn, S., Wu, G. and Kuntaraporn, M. (2006) 'Online word-of-mouth (or mouse): an exploration of its antecedents and consequences', Journal of Computer-Mediated Communication, Vol. 11, No. 4, pp.1104-1127. 
Tax, S.S. and Brown, S.W. (1998) 'Recovering and learning from service failure',Management Review, Vol. 40, No. 1, pp.75-88.

Thøgersen, J., Juhl, H.J. and Poulsen, C.S. (2009) 'Complaining: a function of attitude, personality, and situation’, Psychology \& Marketing, Vol. 26, No. 8, pp.760-777.

\section{Appendix}

\section{A sample scenario to record complaining intentions}

Below you will find several scenarios which may or may not have occurred to you. For each scenario, please select the action(s) you think you might engage in whilst keeping the scenario in mind. Select all that apply.

1 You have just purchased a new cashmere coat for the winter. Once you are home and you have taken the coat out of its packaging you notice that the fabric on the inside of the coat is coming apart from the outside fabric which you had not noticed in-store.

Bearing in mind this situation would you?

\begin{tabular}{l|l}
\hline Take no action & \\
\hline Seek compensation from the seller or manufacturer & \\
\hline Complain to the seller or a government agency & \\
\hline Warn family and friends about the seller/product & \\
\hline Decide to discontinue buying the product & \\
\hline Take legal action to obtain compensation & \\
\hline
\end{tabular}

